\title{
Features of management and factors of economic stability of an industrial enterprise in the region
}

\author{
$E$ A Husainova*, L $R$ Urazbahtina, $N A$ Serkina, $E A$ Dolonina, $A$ A Derbeneva and $O V$ Filina
}

Kazan State Energy University, 420066, Kazan, st. Krasnoselskaya, 51, Russian Federation

\begin{abstract}
The article explores the peculiarities of economic stability of enterprises, gives a brief description of this concept. The economic sustainability of an individual enterprise is being updated for the economic sustainability and competitiveness of the meso-economic system. There is a need to differentiate the concepts of sustainability and balance. Factors of influence on economic stability of the enterprise are considered. The need to manage economic sustainability is argued.
\end{abstract}

\section{Introduction}

At present, with the development of market relations, as well as the increasing impact of exogenous and endogenous factors and increasing competition, the problem of ensuring the economic sustainability of industrial enterprises is being updated.

The emergence of the term "economic sustainability" is due to a study of resource constraints arising from the energy crises of the 1970s and further developed as a separate discipline studying the sustainability of economic development at the meso or macroeconomic levels.

However, it should be noted that regional or country sustainable economic development cannot be achieved without the development of economic sustainability at the micro level, which preserves the potential of the economic system and ensures competitiveness in international markets $[1,2,3]$.

\section{Factors of economic stability of an industrial enterprise in the region}

The development of forms and methods of managing economic stability at the micro level is updated in accordance with the growing importance of the sustainability of enterprises in social and economic development, which is due, on the one hand, to the improvement of the quality and standard of living of the population through the provision of jobs, the production of goods and services, the production of fuel, heat and electricity, etc., and, on the other hand, to the formation and filling of municipal and regional budgets.

There are many definitions of enterprise sustainability. The big encyclopedic dictionary defines the steady enterprise as "... the legal entity which has a structure of a ratio of assets and obligations such is that under all normal conditions sales proceeds or uses of assets are sufficient for a covering of all obligations" [4 and the Big economic dictionary considers stability as "... firmness, regularity, not susceptibility to risk of losses and losses" [5]. According to A. Smit, A. Marshall, D.Keynes, etc., as proponents of the theory of profit maximization, the steady state is called the state of the enterprise, which contributes to maintaining profit at a given level [6 According to L.N. Khramova, the stable state is understood as the ability of the system to function stably taking into account the dynamism of the external environment and to achieve its maximum organization [7]. Thus, the described definitions define stability as a possibility of stable functioning of the system.

The main problems of economic sustainability of industrial enterprises, which constrain the dynamics of their development and functioning in modern conditions, can be identified as high wear and tear of fixed assets, lack of investment resources; Increased tax burden; A high energy intensity that is several times greater than the specific energy intensity of developed country economies; Lack of development and instability of legislation, as well as its non-adaptability to the conditions of operation of industrial enterprises [8].

The industry structure of the Republic of Tatarstan in 2016 (Fig.1.) Practically did not change. So, there was an increase in the share of manufacturing industries by $0.5 \%$ compared to 2015 , the total share was $70.9 \%$, while the share of mining was reduced by $0.4 \%$, which according to the results of 2016 was $22.5 \%$ as well as by $0.1 \%$ to $6.6 \%$, the share of production and distribution of electricity, gas and water decreased[9].

In addition, in 2016 compared to 2015, there was an increase in the share of the engineering industry from $20.2 \%$ to $21.2 \%$, the food industry from $8.5 \%$ to $9.3 \%$, the production of petroleum products, chemistry and petrochemistry from $14 \%$ to $14.2 \%$ and the production of rubber and plastic products from $4.1 \%$ to $4.3 \%[10]$.

The concepts of stability and equilibrium should be distinguished. The stability state can be characterized as

Corresponding author: Ekaterina0686@yahoo.com 


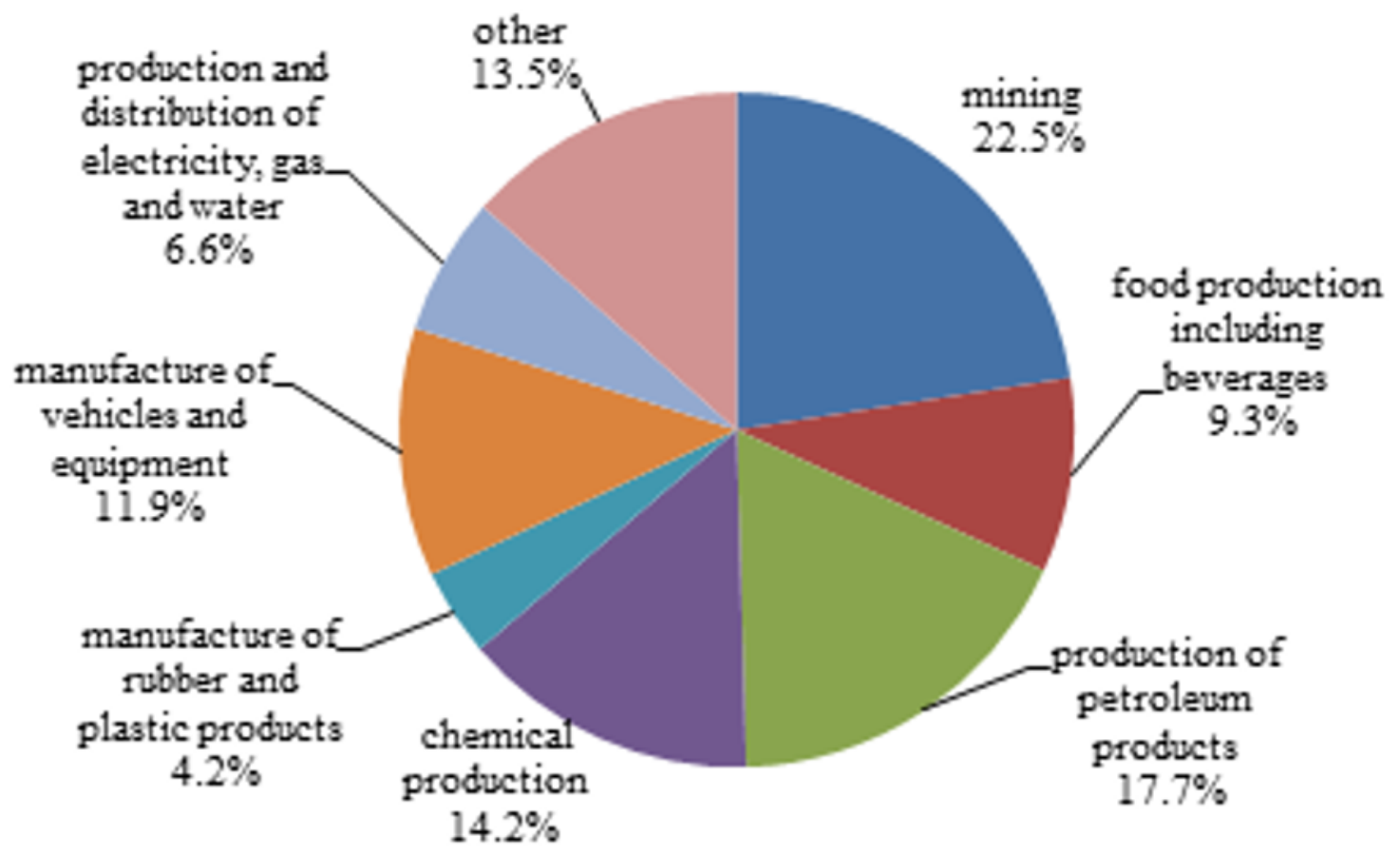

Fig. 1. Industry structure of the Republic of Tatarstan in 2016,\%.

an acceptable performance within existing deviations provided by the enterprise management system. The equilibrium state is presented as the stability of certain indicators of the system taking into account permissible deviations.

Since the purpose of any economic entity is to generate profit, it can be stated that it is the stability of the enterprise in modern conditions that characterizes its ability to preserve the balance and balance of economic resources, which ensure uninterrupted and break-even work [11].

The economic sustainability of an industrial enterprise depends on the impact of exogenous and endogenous factors. Exogenous factors of economic stability of an industrial enterprise determine inflation, depreciation of working capital, terms of settlements with suppliers, dynamics of turnover of funds, imperfect tax system; And the negative impact of endogenous factors is due to low profitability, insufficient effective management of working capital, unjustified credit policy adopted by the enterprise, etc.[12].

The production process includes economic factors "labour," means of work "and" objects of work.

The means of labour and objects of work form the means of production that make up the material maintenance of the production funds, since the production process does not consist only in the creation of products due to the consumption of resources. In the course of the production activity of the enterprise, material costs are incurred for the purpose of simple and extended reproduction of basic and working capital, costs for social development, etc., which require a minimum reserve of economic resources and favorable conditions for their constant resumption, which contributes to maintaining internal economic stability [13].

Thus, it is possible to talk about synergy of investment and production stability of an industrial enterprise as a core indicator of internal stability. This synergy is determined by the expanded reproduction of fixed assets provided by own investments as capital investments in fixed assets reproduction, and the reproduction structure of capital investments is a process of distribution and establishment of their ratio in the total estimated cost divided by forms of reproduction of fixed assets.

Management of economic stability of an industrial enterprise is updated for the following reasons: first, the increasing need to monitor the activity of the enterprise on the basis of a set of signs indicating the current position of the enterprise in the regional environment. Second, increasing the speed of management impacts due to the increasing volume and ease of obtaining information, but the negative point here is the disorderly nature of the indicators optimal for monitoring. Third, the possibility of developing a strategic plan based on self-identification of the enterprise, deep internal analysis and identification of obstacles to successful development. Fourth, increasing the investment attractiveness of the enterprise, which leads to the expansion of the enterprise, the possibility of developing new markets, including outside the region [14].

Consequently, it can be concluded that the management of the economic sustainability of regional enterprises, their functioning and development contributes to their competitiveness, especially in crisis conditions, and consequently increases the 
competitiveness of the meso-economic system as a whole.

However, there is a need to differentiate between the economic sustainability of enterprises operating in economically developed countries and the economic sustainability of enterprises operating in countries with economies in transition. These factors are not always identical, moreover, they can have different effects on the economic sustainability of enterprises [15].

Summarizing the above, we will conclude that modern conditions make it possible to create economic stability of the enterprise under the influence of a system of factors. However, there is some commonality of economically sustainable enterprises, manifested in the characteristics of the entrepreneurial approach in the organization of the enterprise, the efficient use of human capital; The ability to analyse the dynamics of the external environment and to respond promptly to changes; Innovative solutions and dynamism.

\section{References}

1. V.M. Bautin, M.A. Shatalov, Integration of food industry enterprises and related industries on the basis of the cluster approach, Bulletin of the Voronezh State University of Engineering Technologies, 1(63), 210-216 (2015)

2. L.P. Vasilyeva, Management of balanced development of the region: theoretical and practical aspects, Bulletin of Belgorod University of Cooperation, Economics and Law, 2(46), 258-261 (2013)

3. A.Yu.Goncharov, Methodical methods of monitoring and diagnostics of balanced regional development, Bulletin of Belgorod University of Cooperation, Economics and Law, 3(55), 324-331 (2015)

4. Eds. A.M. Prokhorov, Big Encyclopedic Dictionary: $A Z, 2,1452$ (2000)

5. Eds. A.N. Azriliyana, Large Economic Dictionary: 26,500 terms, 7, 1472 (2007)

6. G.M. Golobokova, Economic stability: a tutorial, $326(2011)$

7. L.N. Khramova, Methodical foundations for the sustainable development of the construction company, Author's abstract, dis. Cand. eq., 17 (1998)

8. B.A. Raizberg, Entrepreneurship and risk, 64 (2012)

9. O. K. Tsapieva, Sustainable Development of the Region: Theoretical Foundations and Model [Electronic Resource], Problems of the Modern Economy, 2(34) (2010)

10. M. Fritz, M. Koch, Potentials for prosperity without growth: Ecological sustainability, social inclusion and the quality of life in 38 countries, Ecological Economics, 108, 191-199 (2014)

11. I.T. Shagieva, Management of regional development: the essence and the need for transformation in the context of the modernization of the national economy. Vestnik VSU, Series: economics and management, 2, 127-134 (2013)
12. R.L. Nadeau, The unfinished journey of ecological economics, Ecological Economics, 109, 101-108 (2015)

13. Yu.G. Neudahina, Organizational and economic aspects of managing a region's sustainable development: based on materials from the Kabardino-Balkarian Republic, abstract of a dis.cand., 24 (2011)

14. L.D. Gudkov, Paradoxes of studying social structure in Russia, Historical and socio-educational thought, 8(2\2),207-224 (2016)

15.E.A. Khusainova, Development of tools for monitoring regional economic security, author. dis.kand.ek.nauk, 24 (2018) 